\title{
PENGARUH MENGKONSUMSI MULTIPLE MICRO NUTRIENT (MMN) TERHADAP PENINGKATAN BERAT BADAN IBU HAMIL
}

\author{
RD Rahayu \\ Kementerian Kesehatan Politeknik Kesehatan Surakarta Jurusan Kebidanan
}

\begin{abstract}
MMN, Weight. Pregnant women are one of the vulnerable groups may suffer from anemia because of events that occurred hemodelusi sat pregnancy. MMN is a supplement that contains multivitamins, iron and folate given to pregnant women as one of the Indonesian health ministry programs in an effort to prevent anemia during pregnancy. MMN order to determine the effect on weight gain for pregnant women. The research method to experiment with randomized. The population of 24 male mice. Twenty rats were given MMN. Data analysis using independent t-test. Results: Based on the average value MMN can increase weight gain. There is a difference in weight gain between before and after given MMN.
\end{abstract}

Keyword: $M M N$, Weight

Abstrak: MMN, Berat Badan. Ibu hamil merupakan salah satu kelompok yang rawan dapat mengalami anemia karena peristiwa hemodelusi yang terjadi sat kehamilan. MMN adalah suplemen yang berisi multivitamin, zat besi dan folat yang diberikan pada ibu hamil sebagai salah satu program kementerian kesehatan Indonesia dalam upaya mencegah anemia pada masa kehamilan. Tujuan untuk mengetahui pengaruh MMN terhadap kenaikan berat badan ibu hamil. Metode penelitian dengan eksperimen dengan randomized. Populasi tikus 24 ekor. Dua puluh ekor tikus yang diberi MMN. Analisis data menggunakan independent t-test. Berdasarkan nilai rata-rata $\mathrm{MMN}$ dapat meningkatkan kenaikan berat badan. Ada perbedaan kenaikan berat badan yang signifikan antara sebelum dan sesudah diberikan MMN.

Kata Kunci : MMN, Berat Badan

\section{PENDAHULUAN}

Masalah kematian dan kesakitan ibu di Indonesia masih merupakan masalah besar. Angka Kematian Ibu (AKI) di Indonesia adalah 214 per 100.000 kelahiran hidup (Kemenkes, 2012). Sementara target MDGs adalah menurunkan angka kematian Ibu hingga 3/4 pada tahun 2015 menjadi 102 per 100.000 kelahiran hidup (Depkes, 2012). Sedangkan AKI Propinsi Jawa Tengah tahun 2012 sebesar 116 per 100.000 kelahiran hidup dan jumlah kematian maternal di Kabupaten Klaten sebanyak 19 kematian (Dinkes Jawa Tengah, 2012). Penyebab utama kematian ibu langsung adalah perdarahan $28 \%$, eklampsia $24 \%$, dan infeksi $11 \%$ sedangkan penyebab tidak langsung adalah anemia $51 \%$ (Depkes, 2012). Seorang ibu hamil dikatakan anemia apabila kadar hemoglobin dalam darah di bawah normal yaitu dibawah $11 \mathrm{gr} \%$ pada trimester pertama dan ketiga dan kadar hemoglobin kurang dari 10,5 gr\% pada masa post 
partum dan trimester kedua (Atikah dan Siti, 2009).

Angka kematian ibu di kabupaten klaten dalam kurun waktu tahun 20102014 cenderung mengalami peningkatan. Penyebab kematian ibu karena adanya pernikahan dini, hipertensi dan perdarahan juga faktor-faktor non medis. Kondisi ini menggambarkan derajat kesehatan masyarakat perlu ditingkatkan. Pada tahun 2010 AKI di kabupaten klaten sebanyak 11, tahun 2011 sebanyak 10, tahun 2012 sebanyak 19, tahun 2013 sabanyak 22 dan tahun 2014 sebanyak 20. Kadar hemoglobin yang kurang pada ibu hamil dapat menyebabkan komplikasi yang lebih serius bagi ibu baik dalam kehamilan, persalinan dan nifas yaitu dapat mengakibatkan abortus, partus prematurus, partus lama karena, perdarahan post partum karena atonia uteri, syok, infeksi intra partum maupun post partum.

Anemia berat dengan $\mathrm{Hb}$ kurang dari 4 gr\% dapat mengakibatkan dekompensatio cordis. Sedangkan komplikasi dapat terjadi pada hasil konsepsi yaitu kematian perinatal, prematuritas, cacat bawaan dan cadangan zat besi kurang (Winkjosastro, 2005).

Upaya pemerintah untuk menanggulangi kadar $\mathrm{Hb}$ yang kurang pada ibu hamil yaitu dengan cara memberikan Multiple Micro Nutrient (MMN) sebanyak 120 tablet atau 90 tablet zat besi kepada ibu hamil selama kehamilan yang cukup diminum 1 tablet setiap hari.

Selain untuk menanggulangi kadar $\mathrm{Hb}$ yang kurang, MMN juga bermanfaat untuk menunjang kesehatan ibu hamil selama kehamilannya sedangkan manfaat MMN untuk bayi adalah untuk menunjang dan mengoptimalkan tumbuh kembang janin (Dinkes, 2010).
Konsumsi MMN secara rutin yaitu sebanyak 90 tablet selama kehamilan dapat meningkatkan kadar $\mathrm{Hb}$ pada ibu hamil, menurunkan risiko bayi lahir dengan berat badan rendah, meningkatkan kesehatan ibu selama hamil, saat melahirkan dan sesudah melahirkan serta menurunkan resiko terhadap kematian ibu dan bayi pada saat melahirkan (Depkes, 2012;h.5).

Hasil wawancara yang diperoleh menunjukkan bahwa ibu hamil dengan kadar $\mathrm{Hb}$ rendah mengkonsumsi $\mathrm{MMN}$ $<120$ tablet selama kehamilan sedangkan ibu hamil yang memiliki kadar Hb normal mengatakan selalu mengkonsumsi MMN sebanyak $\geq 120$ tablet selama masa kehamilan yang dialami.

\section{METODE PENELITIAN}

Desain penelitian ini adalah observasional Pendekatan waktu yang digunakan adalah retrospektif. Populasi yang digunakan dalam penelitian ini adalah semua ibu hamil yang memeriksakan kehamilannya di Puskesmas Kalikotes Klaten selama bulan April 2014 yaitu sebanyak 60 orang. Teknik pengambilan sampel yang digunakan adalah purposive sampling adalah peneliti melakukan studi pendahuluan dengan populasi kemudian peneliti menetapkan pengambilan sampel berdasarkan pertimbangan sendiri.

Sampel dalam penelitian ini adalah semua ibu hamil trimester III yang memeriksakan kehamilannya di Puskesmas Kalikotes sebanyak 30 orang. Teknik pengambilan data dengan pengambilan data primer dan sekunder. Instrumen dalam penelitian ini adalah lembar angket. Analisa data menggunakan analisa bivariat dan univariat 


\section{HASIL PENELITIAN}

1. Uji Normalitas data

Hasil uji normalitas didapatkan bahwa dengan menggunakan uji Kolmogorv Sminorf didapatkan nilai $\mathrm{p}=0,056$ jadi p $>0,05$ data normal, jadi uji hipotesis menggunakan independent t-test.

2. Perbedaan kadar hemoglobin ibu hamil kelompok kontrol dan kelompok intervensi

\section{Tabel 1}

\section{Kadar Hemoglobin pada Ibu Hamil} Kelompok Kontrol

\begin{tabular}{lllll}
\hline Kelompok & Mean & N & F & p \\
\hline Sebelum & 4,84 & 4 & 4,753 & 0,004 \\
Sesudah & 5,60 & 4 & & \\
\hline
\end{tabular}

Berdasarkan tabel 1 diketahui

bahwa terdapat perbedaan kenaikan berat badan pada kelompok kontrol dan kelompok intervensi dengan independent $\mathrm{t}$ dan nilai-test didapatkan nilai $\mathrm{F}=4,753$ dan nilai $\mathrm{p}=0,004(\mathrm{p}<0,05)$. Jadi dapat disimpulkan bahwa ada perbedaan kenaikan berat badan pada kelompok intervensi dan kelompok kontrol.

\section{PEMBAHASAN}

Berdasarkan hasil penelitian didapatkan bahwa sari kurma lebih efektif meningkatkan kadar $\mathrm{Hb}$ ibu hamil anemia dibandingkan dengan MMN dengan nilai $p=0,004 \quad(p<0,05)$. Hasil ini sesuai dengan penelitian yang dilakukan oleh Prihanti (2013), bahwa sari kurma berpengaruh terhadap kadar $\mathrm{Hb}$ tikus. Rerata kadar Hb pada kedua kelompok mengalami peningkatan yang bermakna $(\mathrm{p}=0,000)$. Penelitian ini sejalan dengan penelitian di Nigeria yang menyatakan pemberian tablet MNN atau Fe-asam folat dapat menaikkan kadar $\mathrm{Hb}$ pada ibu hamil. Rerata peningkatan kadar $\mathrm{Hb}$ pada kelompok pembanding $(0,89 \mathrm{~g} / \mathrm{dL})$ lebih tinggi daripada kelompok perlakuan $(0,53$ $\mathrm{g} / \mathrm{dL}$ ). Hal tersebut dapat disebabkan oleh 3 hal, penyebab pertama yaitu kadar $\mathrm{Hb}$ awal yang tinggi berpengaruh terhadap penyerapan zat besi yang dikonsumsi dan terhadap peningkatan kadar $\mathrm{Hb}$ akhir. Pada subjek dengan kadar $\mathrm{Hb}$ yang rendah, akan lebih efisien dalam menyerap Fe sehingga peningkatan kadar $\mathrm{Hb}$ akhir menjadi lebih tinggi. Hasil penelitian menunjukkan pemeriksaan kadar $\mathrm{Hb}$ awal pada kelompok pembanding $(9,870 \pm 0,83 \mathrm{~g} / \mathrm{dL})$ lebih rendah dibandingkan rerata kadar $\mathrm{Hb}$ pada kelompok perlakuan $(10,06 \pm 0,70 \mathrm{~g} / \mathrm{dL})$.

Penyebab kedua, komposisi zat besi yang terkandung dalam tablet suplemen yang dikonsumsi pada kedua kelompok berbeda. Tablet MNN (kelompok perlakuan) mengandung $35 \mathrm{mg}$ zat besi sedangkan tablet Fe-Asam Folat (kelompok pembanding) mengandung 60 mg zat besi. Didukung asupan zat besi dari makanan, maka diperoleh rerata asupan zat besi dari makanan lebih tinggi pada kelompok pembanding $(8,62 \mathrm{mg})$ dibandingkan kelompok perlakuan (7,52 mg). Kadar $\mathrm{Hb}$ akan meningkat jika ibu hamil mengonsumsi tablet dengan kandungan zat besi $60 \mathrm{mg}$ dan asam folat $400 \mu \mathrm{g}$ setiap hari selama 3 bulan. Penyebab ketiga, rerata asupan zat gizi lebih tinggi pada kelompok pembanding daripada kelompok perlakuan. Kepatuhan ibu dalam mengonsumsi tablet yang diterima selama kehamilan merupakan faktor yang penting dalam meningkatkan kualitas kehamilannya. Kadar $\mathrm{Hb}$ akan meningkat $1 \mathrm{~g} / \mathrm{dL}$ dalam waktu 1-2 bulan jika ibu hamil mengonsumsi pil besi 60 mg, sehingga kepatuhan ibu hamil merupakan faktor penting dalam menjamin peningkatan kadar $\mathrm{Hb}$ ibu hamil. Penelitian ini menunjukkan bahwa ibu hamil yang mengonsumsi tablet 
suplemen dengan patuh pada kelompok perlakuan sebanyak $47,95 \%$ dan kelompok pembanding 23,4\%.

Hasil penelitian di Nigeria menunjukkan tingkat kepatuhan ibu hamil pada kelompok MNN sebanyak 44,4\% sedangkan kelompok Fe-asam 39 folat $43,8 \%$. Penyebab rendahnya kepatuhan ibu hamil mengonsumsi tablet suplemen adalah faktor kelupaan dan efek samping (mual, muntah, pusing), kurangnya kesadaran tentang pentingnya suplemen dan ancaman anemia bagi ibu hamil, takut bayi lahir besar, dan tidak adanya konseling yang khusus dari tenaga kesehatan.

Analisis multivariat terhadap beberapa variabel yang berhubungan dengan kadar $\mathrm{Hb}$ menunjukkan bahwa variabel jumlah tablet yang dikonsumsi berpengaruh terhadap kadar $\mathrm{Hb}$ dengan memperhatikan asupan zat gizi khususnya vitamin C. Jumlah tablet minimal yang dikonsumsi ibu hamil pada kelompok perlakuan adalah 61 tablet dan maksimal 91 tablet, sedangkan untuk kelompok pembanding konsumsi terendah 75 tablet dan tertinggi 91 tablet. Penelitian menunjukkan bahwa pemberian $30 \mathrm{mg}$ zat besi per hari selama 4 minggu secara teratur dapat meningkatkan kadar $\mathrm{Hb}$ sekitar 2 g/dL. Namun, diperlukan penyuluhan untuk memotivasi subjek agar patuh dalam mengonsumsi tablet. Semakin pendek interval distribusi besi maka akan semakin baik karena semakin sering terjadi kontak antara petugas kesehatan dengan ibu hamil.

Selain jumlah tablet yang dikonsumsi, perlu juga memperhatikan asupan vitamin C. Hasil penelitian menunjukkan rerata asupan vitamin C pada kelompok perlakuan sebesar $67,90 \%$ AKG dan kelompok pembanding sebesar
83,78\% AKG. Vitamin C menghambat hemosiderin yang sukar dimobilisasi untuk membebaskan besi bila diperlukan. Absorbsi besi dalam bentuk non heme akan meningkat menjadi empat kali lipat bila tersedia vitamin C. Vitamin C berperan memindahkan besi dari transferin di dalam plasma ke feritin hati. Hal ini sesuai dengan penelitian yang menunjukkan bahwa pemberian $50 \mathrm{mg}$ vitamin $\mathrm{C}$ setiap hari selama 2 bulan mampu menaikkan kadar $\mathrm{Hb}$. Penambahan sekurang-kurangnya $50 \mathrm{mg}$ vitamin $\mathrm{C}$ ke dalam makanan, baik dalam bentuk murni atau sayuran dan buahbuahan akan meningkatkan penyerapan zat besi.

Penambahan berat badan Selain dari asupan energi dan protein, banyak faktor yang dapat mempengaruhi kenaikan BB ibu hamil antara lain keadaan ekonomi, paritas, umur ibu, pendidikan ibu, aktivitas, anemia, dan status gizi. Rerata kenaikan BB ibu hamil pada kelompok perlakuan lebih tinggi dibandingkan kelompok pembanding meskipun perbedaan kenaikan BB secara statistik tidak bermakna $(p=0,96)$. Hasil penelitian yang sama di Nusa Tenggara Barat menunjukkan bahwa tidak ada perbedaan bermakna penambahan BB ibu antara ibu hamil yang mengonsumsi multi gizi mikro dan Fe-asam folat.

Hasil penelitian ini menunjukkan bahwa ibu hamil anemia yang mengalami kenaikan BB sebanyak 39 orang $(69,6 \%)$ sedangkan jumlah ibu hamil tidak anemia yang naik berat badannya sebanyak 30 orang $(76,9 \%)$. Anemia yang berat dapat menimbulkan gejala pada saluran pencernaan yang umumnya berhubungan dengan defisiensi zat besi seperti anoreksia (tidak ada nafsu makan), nausea, konstipasi, diare, dan stomatis 
(sariawan lidah dan mulut) yang nantinya akan mempengaruhi asupan zat gizi. Sebaliknya, jika kelebihan zat besi menyebabkan kondisi melemah yang dapat menyebabkan kerusakan hati, jantung, pankreas, dan organ lainnya.

Analisis multivariat terhadap beberapa variabel yang berhubungan dengan kenaikan BB menunjukkan bahwa variabel yang berpengaruh terhadap kenaikan BB ibu hamil adalah jumlah tablet suplemen yang dikonsumsi. Komposisi pada tablet MNN lebih lengkap kandungan mikronutriennya dibandingkan tablet Fe-asam folat. Selain mengandung zat besi dan asam folat juga mengandung vitamin $B$ yang dapat meningkatkan nafsu makan dan mencegah mual serta muntah pada masa kehamilan sehingga dengan memberikan multi mikronutrien status gizi ibu hamil dapat lebih optimal.

\section{KESIMPULAN DAN SARAN}

A. Kesimpulan

Berdasarkan hasil penelitian didapatkan kesimpulan sebagai berikut

1. Berdasarkan nilai rata-rata $\mathrm{MMN}$ dapat meningkatkan kenaikan berat badan.

2. Ada perbedaan kenaikan berat badan yang signifikan antara sebelum dan sesudah diberikan MMN.

B. Saran

1. Masyarakat terutama ibu hamil harus mengkonsumsi MMN sebagai solusi alternatif untuk mencegah penurunan $\mathrm{BB}$.

2. Melihat hasil penelitian perlu dilakukan penelitian lebih lanjut tentang keefektifan konsumsi tablet MMN.

\section{DAFTAR RUJUKAN}

Abdulmuthalib (2008) Kelainan

Hematologi Dalam Buku Ilmu

Kebidanan. Jakarta: Bina Pustaka;. hal 774-780

Cunningham G.F., Gant N.F., Leveno K.J., et all. 2006. Obstetri Williams vol 1 edisi 21 . Jakarta: EGC:

Dahlan M. Sopiyudin (2009).Statistika Untuk Kedokteran Dan Kesehatan. Jakarta: Salemba medika

Guyton (1997) Fisiologi Kedokteran, Jakarta, EGC

Nita Dalmiya, Ian Darnton-Hill, Werner Schultink, and Roger Shrimpton (2009). Multiple micronutrient upplementation during pregnancy, Food and Nutrition Bulletin, vol. 30, no. 4 (supplement) United Nations University Press

Dinas Kesehatan Klaten. 2012. Petunjuk Tehnis MMN

Robert K. Murray (2006). Sel Darah Merah Dan Putih Dalam Buku Biokimia Harper edisi 27 . Jakarta: EGC; hal 636-652

Sugiyono (2007).Statistika Untuk Penelitian. Bandung: CV Alfabeta

Varney, Helen. (2007). Buku AjarAsuhan Kebidanan Edisi 4 Volume 1. Jakarta:EGC 